Agro-Science Journal of Tropical Agriculture, Food, Environment and Extension Volume 15 Number 1 January, 2016 pp. 29-33

ISSN 1119-7455

\title{
GROWTH PERFORMANCE OF GRASSCUTTERS FED DIETS CONTAINING Moringa oleifera LEAF MEAL AND/OR SOYBEAN MEAL
}

\author{
Akuru*, E.A., Dim, C.E., Ozioko, C.M. and Ugwu, S.O.C. \\ Department of Animal Science, Faculty of Agriculture, University of Nigeria, Nsukka, Nigeria \\ *Corresponding author's email: eunice.iloh@unn.edu.ng
}

\begin{abstract}
A total of ninety six-week old grasscutters were used in a study conducted to investigate the growth performance of grasscutters fed diets containing Moringa oleifera leaf meal (MOLM) and/or soybean meal $(S B M)$. The ninety (90) grasscutters were randomly assigned to three experimental groups consisting of thirty (30) grasscutters each. The grasscutters were randomly assigned each to three experimental diets designated as follows: $15 \%$ MOLM, 15\% SBM, and 10\% MOLM + 10\% SBM. Feed and water were provided ad libitum. Data were collected on growth performance during the period of the study which lasted for ten weeks including two weeks of acclimatization period. Results showed that grasscutters fed diet containing $10 \%$ MOLM+10\% SBM had significantly ( $p<0.05)$ higher performance indices than grasscutters on other treatment diets, except for feed conversion ratio, where grasscutters fed diet 1 (15\% MOLM,) had the least FCR than grasscutters in other groups. Based on the results, the inclusion of MOLM and SBM at 10\% levels each resulted in improved performance, and thus considered adequate for growth of grasscutters.
\end{abstract}

Key words: micro-livestock, captive, productivity, grasscutters, feeding

\section{INTRODUCTION}

Grasscutters (Thryonomys swinderianus) occur throughout West Africa, and are regarded as a major micro-livestock with potential for increasing animal protein intake particularly in low income countries (Edna et al., 2008; Adesope, 1996). As hardy, hystricomorphic rodents, grasscutters possess high breeding potential (Henry, 2011). Grasscutters display a seasonal breeding pattern, with breeding time affected mostly by prevailing weather conditions and location of the animal on the African continent (Fitzinger, 1997). Females generally have two litters per year, with an average of four offspring per litter (Mills, 1997). With an average gestation period of 137-172 days, female grasscutters have an oestrous cycle that last for over six days, and produce relatively well developed offspring with an average birth mass of 129 grams (Fitzinger, 1997). Being robust animals, grasscutters become sexually mature at about a year old, measuring up to $60 \mathrm{~cm}$ (head and body) and weighing more than $9 \mathrm{~kg}$ (Fitzinger, 1997; Henry, 2011). Free from religious and societal taboos, grasscutter meat, popularly called 'bush meat' is highly preferred by consumers in Nigeria to other meat products. This is due to its rich source of animal protein with high biological value. The meat also has a high dressing percentage, low fat content, and high mineral content and unique taste.
All these make grasscutter meat of higher quality than the meat of domestic animals like sheep or goats (Olomu et al., 2003; Opara, 2010b).

Despite the high promise of good quality animal protein from grasscutters, the nutritional factor is however an important consideration in all livestock production, particularly as productivity of animals is often affected by feed type (Keunen et al., 2002). Hence, feeding is regarded as the most essential factor affecting the production of captive animals like grasscutters. This is attributable to the myriads of challenges such as increased mortality, low productivity, low birth weight, and so on, arising from feeding low quality diets to these animals (Ansah et al., 2012). Due to all season availability, the use of forages like Leucena, sugarcane, sweet potato vines and Moringa leaves have been proposed as one of the ways of addressing the nutritional constraints associated with low feed quality and improving productivity especially in micro-livestock. Of particular interest is the place of Moringa oleifera leaf meal in the diet of herbivorous microlivestock such as grasscutters which seem to have high preference for thick-stemmed grass species. Moringa oleifera is among the most effective forage additives for micro-livestock due to its relatively low cost, exceptional nutrient density and high nutrient absorption rates (Schrage and Yewadan, 1999; Moringa source, 2011). 
The presence of flavonoids like quercetin and kaempferol in Moringa leaves confers it with strong antioxidant properties (Siddhuraju and Becker, 2003). The use of supplements, along with the feeding of roughages has been found to improve performance in animals. In view of this, soybean has been reported to be the most widely used protein supplement in animal feeds (Agboola, 2000; Schwab, 1999). As a vegetable protein, soybean is reputed for its high quality crude protein and amino acid composition, with low crude fibre value of $6 \%$ when compared to other vegetable protein feeds (Banaszkiewicz, 2000). The aforementioned facts notwithstanding, there is a dearth of information on the growth performance of grasscutters under different dietary regimes. This study was therefore designed to investigate the growth performance of grasscutters fed Moringa oleifera leaf meal and/or soybean based diets.

\section{MATERIALS AND METHODS}

The study was carried out at the Grasscutter Research Unit of the Department of Animal Science, University of Nigeria, Nsukka. The experiment lasted for ten weeks with an initial 2 weeks acclimatization period. Three experimental diets were formulated to contain 15\% Moringa oleifera leaf meal (MOLM), $15 \%$ soybean meal (SBM), and $10 \%$ Moringa oleifera leaf meal+ $10 \%$ soybean meal (10\% MOLM+ 10\% SBM) respectively. The percentage compositions of the diets are shown in Table 1.

\section{Grasscutters and Experimental Design}

A total of 90 six-week old, large-sized grasscutters (having initial body weight of 832-843 g) procured from Demaco Farms, Enugu State, Nigeria were used for the study. They were randomly divided into three treatment groups of 30 grasscutters per group. The groups were randomly assigned to the

Table 1: Percentage composition of experimental diets

\begin{tabular}{|c|c|c|c|}
\hline \multirow[t]{2}{*}{ Ingredients } & \multicolumn{3}{|c|}{ Treatments } \\
\hline & $\mathrm{T} 1$ & $\mathrm{~T} 2$ & T3 \\
\hline Maize & 10.00 & 34.00 & 32.00 \\
\hline Wheat offal & 34.00 & 28.00 & 23.00 \\
\hline Palm kernel cake & 36.00 & 18.00 & 20.00 \\
\hline Soybean meal & 0.00 & 15.00 & 10.00 \\
\hline Moringaoleifera & 15.00 & 0.00 & 10.00 \\
\hline Bone meal & 4.00 & 4.00 & 4.00 \\
\hline Lysine & 0.25 & 0.25 & 0.25 \\
\hline Methionine & 0.25 & 0.25 & 0.25 \\
\hline *Vitamin premix & 0.25 & 0.25 & 0.25 \\
\hline Salt & 0.25 & 0.25 & 0.25 \\
\hline Total & 100.00 & 100.00 & 100.00 \\
\hline \multicolumn{4}{|l|}{ Calculated composition } \\
\hline Crude protein & 17.06 & 17.84 & 17.78 \\
\hline Energy (Mcal/kg ME) & 2.07 & 2.45 & 2.41 \\
\hline Crude fibre & 8.48 & 6.19 & 6.29 \\
\hline \multicolumn{4}{|c|}{ 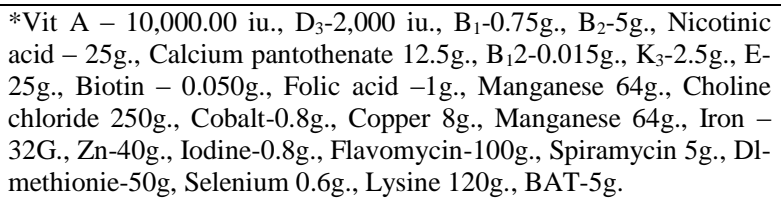 } \\
\hline
\end{tabular}

three experimental diets containing 15\% MOLM, $15 \%$ SBM, and $10 \%$ MOLM+ $10 \%$ SBM, respectively in a completely randomized design (CRD). The grasscutters were housed in concrete pens facing North-South direction to avoid excessive penetration of sunlight and consequent heat stress. The floors of the pens were cleaned daily, water and feed troughs were also washed daily, beddings were changed at 3 days interval to maintain optimum sanitation and health status.

\section{Management of Experimental Animals and Data Collection}

The grasscutter pens were washed and disinfected two weeks prior to the arrival of the animals. Medication was given to the grasscutters by a Veterinarian. Feed and water were offered ad libitum. The weight of the feed offered minus the weight of left over feed was recorded as the daily feed intake. The grasscutters were weighed at the beginning of the experiment to obtain their initial body weights, and subsequently on weekly basis to determine their growth performance. The animals were finally weighed at the end of the experiment to determine their final live weights. Feed conversion ratio was calculated from these data as quantity (gram) of feed consumed per unit (gram) weight gained over the same period.

\section{Proximate Composition of Feed and Statistical Analysis of Data}

Experimental diets were subjected to proximate analysis according to AOAC (2006). The Moringa oleifera leaves which were purchased from a local market were dried under shade for 10 days and thereafter the leaves where threshed carefully to separate leaves from twigs before blending to obtain the leaf meal. The dried leaves were ground to powder using an electric blender. Soybean meal was procured from a commercial feed mill in Nsukka, Enugu, Nigeria. Data were analyzed using the One way analysis of variance (ANOVA) in a completely randomized design (CRD) with the statistical package for social science (SPSS) version 20.0 (SPSS, 2007). Significantly different means were separated using Duncan's New Multiple Range Test option in SPSS (2007).

\section{RESULTS}

Effect of $M$. oleifera Leaf Meal and/or Soybean Meal on Growth Performance of Grasscutters

The proximate compositions of the experimental diets are shown in Table 2. Table 3 shows the growth performance of grass-cutters fed diets containing Moringa oleifera meal and/or soybean meal. There were significant differences $(\mathrm{p}<0.05)$ among treatments in final and cumulative body weights. Grasscutters on treatment $3 \quad(10 \%$ MOLM+10\%SBM) had significantly higher ( $\mathrm{p}<$ 
0.05) final and cumulative body weights than those on the other treatments. The final and cumulative body weights of grasscutters on treatment $2(15 \%$ SBM) were also significantly higher $(\mathrm{p}<0.05)$ than those of grasscutters fed treatment 1 (15\% MOLM) whose final and cumulative body weights were significantly $(p<0.05)$ lower than those on the other treatments. The daily weight gain of grasscutters on treatment 1 was significantly lower $(\mathrm{p}<0.05)$ than those on the other treatments, with treatment 2 having the highest daily weight gain. Although, grasscutters on treatment 1 had the least feed intake, it was not significantly $(p>0.05)$ different from the feed intake of grasscutters fed treatment 3. The feed intake of grasscutters on treatment 2 was higher $(p<0.05)$ than that of those on the other treatments. The feed conversion ratio values differed significantly $(\mathrm{p}<0.05)$ across the various treatments with grasscutters on treatment 1 having the least FCR value, while grasscutters on treatment 2 had the highest FCR value.

\section{DISCUSSION}

As shown in Table 3, feed intake was lowest among grass-cutters fed $15 \%$ Moringa oleifera leaf meal (MOLM). Obi et al. (2008) reported that crude fibre content of a diet usually affect feed consumption, invariably, the higher the crude fibre of the feed, the lower the feed consumed. From the data for the proximate analysis of the experimental diets (Table 2), treatment 1 diet had the highest crude fibre content and this probably may have impacted on the feed intake of grasscutters on that diet. According to Kung and Grueling (2000), high dietary fibre resulted in the limitation of the amount of energy available to poultry birds with consequent increase in the amount of nutrients excreted. Lee et al. (2003) reported that inclusion of fibre in the diets of monogastrics like poultry species has been discouraged owing to the negative effect it has on performance and nutrient utilization. It is also probable that the feed intake of grasscutters on treatment 1 may have been affected by the characteristic odour of MOLM. Makkar and Becker (1997) reported that moringa leaves had antinutritive factors like saponins which are responsible for its characteristics odour. Saponins are bitter and so reduce palatability of livestock feeds and this may be responsible for the decrease in feed intake noticed in grasscutters fed 15\% MOLM.

Table 2: Proximate composition of experimental diets

\begin{tabular}{lccc}
\hline Components $(\%)$ & \multicolumn{3}{c}{ Treatments } \\
& $\mathrm{T}_{1}$ & $\mathrm{~T}_{2}$ & $\mathrm{~T}_{3}$ \\
\hline Dry Matter & 90.40 & 92.31 & 88.57 \\
Ether extract & 2.55 & 3.20 & 3.30 \\
Ash & 9.60 & 4.05 & 5.30 \\
Fibre & 13.03 & 7.69 & 11.43 \\
Protein & 17.73 & 13.48 & 14.44 \\
Nitrogen free extract & 47.49 & 63.89 & 54.10 \\
\hline
\end{tabular}

$\mathrm{T}_{1}-15 \%$ MOLM; $\mathrm{T}_{2}-15 \% \mathrm{SBM} ; \mathrm{T}_{3}-10 \% \mathrm{MOLM}+10 \% \mathrm{SBM}$
Although grasscutters on 15\% MOLM had better feed conversion ratio (FCR) values than those on the other treatment, this did not translate into higher final and cumulative body weights and also average daily weight gain (ADWG). This result corroborates that of Adu et al. (2010), who observed a significant reduction in live weight among grasscutters fed Panicum maximum plus Moringa oleifera leaf meal, compared to those on Panicum maximum plus sweet potato vine based diet. The authors attributed this to the findings of Schrage and Yewadan (1999) which showed that grasscutters tend to prefer the more succulent portions of forages which the Panicum maximum plus Moringa oleifera leaf based diets could probably not afford them. It is well known that feed intake is a major factor influencing weight gain. Thus, reduction in weight gain observed among grass-cutters that consumed 15\% MOLM diets may be attributed to depressed feed intake and lower efficiency of feed utilization (Ani and Okeke, 2011). In some earlier reports (Ani and Okorie, 2004; Ani, 2007; Ani and Okorie, 2007), it was observed that growth depression was directly linked to reduced feed intake. As the average daily feed intake (ADFI) per grasscutter decreased, the grasscutters receiving these diets did not have sufficient dietary nutrients, hence, the resultant depressed growth. Consequently, the metabolic and production requirements of these grasscutters could not be met with the decline in feed intake.

Several studies (Wang et al., 2000; Douglas, 1999; Mankind et al., 1996) have confirmed that daily gain in body weight and feed conversion are lower in animals fed diets containing trypsininhibitor, and lectin, which is anti-nutritive factors present in soybean, the reverse was however, the case in this study. It was observed that although grasscutters on treatment $2(15 \%$ SBM $)$ had the highest average daily weight gain, (ADWG), their average daily feed intake (ADFI) and feed conversion ratio (FCR) values were the highest compared to those on the other treatments. The better weight gain recorded in treatment 2 over treatment 1 and treatment 3 may be attributed to the increased feed intake which could be due to low fibre content of the diet. This result is in line with the findings of Fayenuwo et al., (2003) who reported that grasscutter prefer feeds that are succulent and sweet and low in fiber contents. More so, it has been reported that feed intake is a major factor affecting weight gain, thus, growth depression is often directly linked to reduced feed intake. Notwithstanding, Esonu et al. (2010) reported that inclusion of $30 \%$ soybean hull (with/without safzyme® supplementation) in the diet of laying birds increased the feed intake of birds, attributing it to the high fibre content of soybean hulls which tend to increase the total fibre content of the diet and dilute other nutrients. 
Table 3: Growth performance of grass-cutters fed experimental diets

\begin{tabular}{|c|c|c|c|}
\hline \multirow[t]{2}{*}{ Parameters } & \multicolumn{3}{|c|}{ Treatments } \\
\hline & $\mathrm{T}_{1}$ & $\mathrm{~T}_{2}$ & $\mathrm{~T}_{3}$ \\
\hline Initial body weight (g) & $832.17 \pm 9.94$ & $843.62 \pm 9.95$ & $838.43 \pm 9.94$ \\
\hline Final body weight (g) & $1671.72 \pm 9.30^{\mathrm{c}}$ & $1779.97 \pm 9.30^{\mathrm{b}}$ & $1871.63 \pm 9.30^{\mathrm{a}}$ \\
\hline Cumulative body weight (g) & $838.10 \pm 11.89^{c}$ & $947.80 \pm 11.89^{\mathrm{b}}$ & $1033.20 \pm 11.89^{\mathrm{a}}$ \\
\hline ADWG (g) & $13.50 \pm 11.83^{c}$ & $15.63 \pm 11.83^{\mathrm{a}}$ & $14.76 \pm 11.83^{\mathrm{b}}$ \\
\hline $\mathrm{ADFI}(\mathrm{g})$ & $43.29 \pm 0.00^{\mathrm{b}}$ & $50.71 \pm 0.00^{\mathrm{a}}$ & $45.10 \pm 0.00^{\mathrm{b}}$ \\
\hline FCR $(g)$ & $3.06 \pm 0.52^{\mathrm{c}}$ & $4.29 \pm 0.52^{\mathrm{a}}$ & $3.96 \pm 0.52^{\mathrm{b}}$ \\
\hline
\end{tabular}

Means on the same row with different superscripts are significantly different ( $\mathrm{p}<0.05)$. $\mathrm{T}_{1}-15 \% \mathrm{MOLM}$; $\mathrm{T}_{2}-15 \% \mathrm{SBM}$;

$\mathrm{T}_{3}-10 \%$ MOLM+10\% SBM; ADWG- Average daily weight gain; ADFI- Average daily feed intake; FCR- Feed conversion ratio.

However, the high FCR value of these grasscutters may be probably due to the presence of anti-nutritional factors like trypsin-inhibitor and lectin present in the soybean which according to Chunmei (2010), Herkerman et al. (1992) and Schulze et al. (1993a) affects the nutritional value, utilization and digestibility of soybean. This may be the reason for increased feed intake among grasscutters on treatment 2 translating into higher gain weight, though not so much different from that of grasscutters on treatment 3 .

\section{CONCLUSION}

The results obtained in this study show that the inclusion of MOLM and SBM each at 10\% levels resulted in improved performance, and thus considered adequate for growth of grasscutters.

\section{REFERENCES}

Adesope, O.M. (1996). Using local action process to increase Grasscutter production: Implication for extension services. Nigerian Society for Animal Production (NSAP) Conference at the University of Uyo, Akwa-Ibom State

Adu, E.K., Bagulo, H. and Amaning-Kwarteng, K. (2010). The effects of incorporation of Moringa oleifera leaves and sweet potato vines in the ration of growing grasscutters (Thryonomys swinderianus Temminck). Livestock Research for Rural Development. 22 (6)

Agboola, P.O. (2000). Grascutter farming seminar paper presented at Forest and Wildlife Conservation Division, Forest Research Institute, Ibadan, Nigeria.

Ani, A.O. and Okeke, G.C. (2011). The performance of broiler birds fed varying dietary levels of roasted pigeon pea (Cajanus cajanus) seed meal. Pakistan Journal of Nutrition, 10 (11), 1036-1040

Ani, A.O. (2007). Effects of graded levels of dehulled and cooked castor oil bean (Ricinus communis) meal and supplementary L-lysine on the performance of broiler finishers. Agro-Science, 6 (1), 89-97

Ani, A.O. and Okorie, A.U. (2004). The effect of dietary castor oil bean (Ricinus communis) meal and supplementary L-lysine on the performance of broiler starter chicks. Discovery and Innovation, 16 $(1 / 2), 46-52$
Ani, A. O. and Okorie, A.U. (2007). Performance of broiler chicks fed graded levels of processed castor oil bean (Ricinus communis) meal and supplementary DL-Methionine. Tropical Journal of Animal Science, 10 (1 and 2), 289-295

Ansah, T., Agbolosu, A. A., Teye, G.A., Akwasi, A. and Opoku-Agyeman, M. (2012). Evaluation of Corn Cob on the growth performance of Grasscutter (Thryonomys swinderianus). Animal Science and Biotechnologies. 45 (1)

AOAC, (2006). Official Methods of Analysis. $18^{\text {th }}$ Ed., Association of Official Analytical Chemists, Washington D.C.

Banaszkiewicz, T. (2000). Nutritive Value of New Rape Cultivars Stated in the Test for Broiler Chickens (in Polish). Thesis University of Podlasie, 61, 1-99, PL 1 SSN 0860

Chunmei, G., Hongbin P., Zewei, S. and Guixin, Q. (2010). Effect of soybean variety on anti-nutritional factors content, and growth performance and nutrient metabolism in rat. Int. J. Mol. Sci. 11, 1048-1056. doi: 10.3390/ijms11031048

Dei, H.K., Rose, S.P. and Mackenzie, A.M. (2007). Shea nut (Vitellaria paradoxa) meal as a feed ingredient for poultry. In World's Poultry Science Journal, 63 (4), 611-624

Douglas, J.S. (1999). Recommended compositional and nutritional parameters to test in soybeans. Report No A59915. Technical Assessment Services, Washington D.C.

Edna, C., M-N., Adesope, O.M. and Nodu, M.B. (2008). Socio-economic characteristics associated with rural households perception about grasscutter meat cost in the Niger Delta zone of Nigeria. Pakistan Journal of Social Sciences, 5 (4), 360-362

Esonu, B.O., Iheshiulor, O.O.M., Chukwuka, O.K., Omede, A.A. and Ogbuewu, I.P. (2010). Performance characteristics and haematology of laying birds fed Safzyme ${ }^{\circledR}$ supplemented soybean hull diet. Report and Opinion. 2 (8)

Fayenuwo, J.O., Akande, M., Taiwo, A.A., Adebayo, A.O., Saka, J.O., Lawal, B.O., Tiamiyu, A.K. and Oyekan, P.O. (2003). Guidelines for grasscutter rearing. Technical Bulletin, IAR \& T., Ibadan. p. 38

Fritzinger, R. (1997). Cane Rats. In: Walker's Mammals of the World. Nowak, R (Ed.). The John Hopkins University Press (pp. 1650-1651)

Henry, A.J. (2011). Reproductive performance of grasscutter does at first parity and growth performance of their $\mathrm{F}_{1}$ generation. Asian Journal of Animal Sciences. 5, 289-295 
Herkelman, K.L., Cromwell, G.L., Stahly, T.S., Pfeiffer, T.W. and Knabe, D.A. (1992). Apparent digestibility of amino acids in raw and heated conventional and low trypsin inhibitor soybean for pigs. J. Nutri. Sci. 70, 818-826

Keunen, J.E., Plaizier, J.C., Kyriazakis, L., Duffield, T. F., Widowski, T.M., Lindinger, M.I. and McBride, B.W. (2002). Effect of subacute rumina; acidosis model on the diet selection of dairy cows. Journal of Dairy Science, 85 (85), 3304-3313. Available at: www.ncbi.nlm.nih.gov/pubmed/12512604

Kung, P. and Grueling, H.T. (2000). Enzyme supplementation of a poultry diet containing rye and wheat. Br. J. Nutr. 62,139-149

Lee, J.J., Sally, N., Antonio R. and Jerry, S. (2003). Feeding by-products high in concentration of fiber to non-ruminants. Presented at the Third National Symposium on Alternative Feeds for Livestock and Poultry held in Kansas City, MO on November 4

Makind, M.O., Umapathy, E., Akingbem, B.T.I., Manisodza, K.T. and Skadhasuge, E. (1996). Effects of dietary soybean and cowpea on gut morphology and faecal composition in creep and non-creep fed pigs. J. Vet. Med. Ser. A, 43, 75-85

Makkar, H.P.S. and Becker, K. (1997). Nutrients and antiquality factors in different morphological parts of the Moringa oleifera tree. J Agric Sci., 128 (3), 311-22

Mills, G.L. (1997). The complete book of South African mammals. Cape town: Struik Winchester. pp. 68-89

Moringa-source (2011). Nature's most nutritious superfood. Nursing Animals Love Moringa Powder. http://www.moringasource.com/blog/84/nursinganimals-love-moringa-powder

Obi, O.O., Omole, A. J., Ajasin, F.O. and Tewe, O.O. (2008). Nutritional potentials of four conventional forages fed to growing grasscutters (Thryonomys swinderianus). Livestock Research for Rural Development. 20 (11)
Olomu, J.M., Ezieshi, V.E. and Orheruata, A.M., (2003). Grasscutter production in Nigeria. Principles and Practice. Jachem Publishers. p. 62

Opara, M. N. (2010b). The Grasscutter: A Livestock of Tomorrow. Research Journal of Forestry 4,119-135

Schrage R. and Yewadan, T. (1999). In: Raising grasscutters. Deutsche Gesellschaft fur Technische Zusammenarbeit (GTZ) GmbH, Eschborn, Germany, pp. 37-47

Schulze, H., Verstegen, M.W.A., Huisman, J., VanLeeuwen, P. and Van de Berg, J.W.O. (1993a). Nutritional effects of isolated soya trypsin inhibitor on pigs. In: Recent Advances of Research in Antinutritional Factors in Legume Sees; Van de Poel, A. F.B. Husman, J., Sini, H.S., (Eds.), Pudoc; Wageningen, The Netherlands, pp. 195-199

Schwab, (1999). Protected proteins and amino acids for ruminants. In: Biotechnology in Animal Feeds and Animal Feeding (pp. 115). VCH. NY

Siddhuraju, P. and Becker, K. (2003). Antioxidant properties of various solvent extracts of total phenolic constituents from three different agroclimatic origins of drumstick tree (Moringa oleifera Lam.) leaves. Journal of Agricultural \& Food Chemistry, 51, 2144-2155

SPSS.com. (2007). IBM ${ }^{\circledR}$ SPSS ${ }^{\circledR}$ Advantage for Microsoft ${ }^{\circledR}$ IBM.Corporation Route, 100, Somers, N4. 10589

Wang, S.P., Qin, G. X., Gong, Q. and Yang, L.Y. (2000). Effect of anti-nutritional factors in full fat soybean on the performance of broilers [in Chinese]. J. Jilin Agric. Univ., 22, 81-86 